\title{
"Rosalina" marginata REUSS 1845 (Foraminifera) and its taxonomic positions
}

\section{Theodor NEAGU}

\author{
Laboratory of Paleontology, University of Bucharest, N. Bălcescu Blvd. 1, Bucharest, Romania
}

Received December 2011; accepted March 2012

Available online 3 June 2012

DOI: $10.5038 / 1937-8602.57 .2 .4$

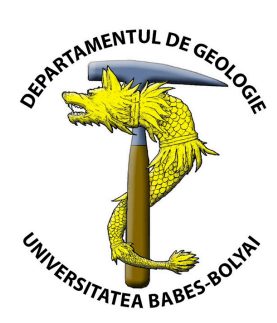

\begin{abstract}
The central idea of this article is the obligation of a micropaleontologist to respect without any doubt the rules and demands stipulated by the International Commission on Zoological Nomenclature (ICZN), in order to avoid taxonomical mistakes. An unusual example of confusion generated by disregard for the ICZN Code rules is the case of Rosalina marginata REUSS. The species Rosalina marginata REUSS, 1845 emend. REUSS, 1854 is here transferred to the genus Dicarinella. Other specimens illustrated as "Marginotruncana marginata" for example the "neotype" established by Jirova (1956) are placed in the new species Marginotruncana pseudomarginata nom. novum.
\end{abstract}

Key words: Upper Cretaceous, planktonic foraminifera, taxonomy, new name.

\section{INTRODUCTION}

\section{Historical review}

In his monumental monograph "Versteinerungen der bohemischen Kreideformation", Reuss (1845) described a large number of foraminifera, together with an impressive fossil assemblage (from plants to fishes). Among the foraminifera Reuss illustrated was Rosalina marginata (p. 36, P1. 8, Fig. 54, 74, P1. 13, Fig. 86). Besides the dimensions and description, Reuss also figured the spiral and umbilical views of this foraminifer, but unfortunately the illustrations are very small and practically useless. Reuss (1854) again found this species and corrected the illustration of the umbilical and spiral sides, showing the presence of two very nearly peripheral keels. In this manner, Reuss (1854) changed his opinion on this species by redescribing and making an excellent illustration of the test in three typical views (umbilical, spiral and latero-oral).

Unfortunately, authors who have dealt with Upper Cretaceous foraminiferal associations (including the Catalog of Ellis \& Messina) only take into account the work from Reuss's 1845 monograph, but as I have noted, the illustrations cannot be practically used.

In 1946, in his monograph "Upper Cretaceous foraminifera of the Gulf Costal region of the United States and adjacent area", Joseph Cushman commented on this species: "This species has been referred to Globigerina by many authors, but the figures are not usually very definite and have not been referred to here [...] Reuss's collections (Dresden, Vienne, and Cambridge) all show specimens evidently derived from a globigerinid ancestor, but the later chambers especially are compressed, have definite dorsal and ventral keels and the periphery becomes truncated" and he finally concluded: "His figures (Reuss, 1845) are too minute to be of much value". Cushman, like many authors when presenting this species, totally overlooked the fact that Reuss auto-emended his species in 1854 in a diagnosis connected with an excellent illustration (as already shown).

Hofker (1956) defined a new genus, Marginotruncana, breaking the homogeneity and exaggerated uniformity associated with the genus Globotruncana, and designated as type species of his new genus "Rosalina" marginata, REUSS, 1845.

Bolli et al. (1957) in their paper "Planktonic foraminiferal families Hantkeninidae, Orbulinidae, Globorotaliidae and Globotruncanidae" contested the taxonomical value of Hofker's new genus, trying also to understand that the genus Globotruncana is not so uniform.

Pessagno (1967) in his monograph "Upper Cretaceous planktonic foraminifera from the Western Gulf Costal Plain" demonstrated the validity of the genus Marginotruncana, emending Hofker's original diagnosis. In the presentation of the species Marginotruncana marginata, both of Reuss's papers from 1845 and 1854 are noted in the synonymy. In a footnote (p. 307) Pessagno wrote: "the writer learned that a neotype had been established for Rosalina marginata by Jirova (1956), although Jirova's neotype differs morphologically at the species level from the form figured herein (Pessagno, 1967) as Marginulina marginata (REUSS), the writer feels that it should be accepted to propagate taxonomic stability".

Among the studies carried out by authors which presented the species " $R$ " marginata REUSS, 1845, Pessagno (1967) is the only one who also takes into consideration the specimen of $R$. marginata presented by Reuss (1854, Fig. 1a-c). These illustrations are important because they are large, clear, and certainly illustrate his concept of this species. The figured specimen shows six 
chambers in the final whorl separated by curved slightly raised sutures, spirally and by radial straight depressed sutures umbilically. The umbilicus or umbilical area is large and narrow, and double keels are present in the last whorl".

All of these characters clearly mentioned by Pessagno (1967) are totally absent from the neotype presented by Jirova (1956) in her article "The genus Globotruncana in Upper Turonian and Emscherian of Bohemia". Unfortunately for those not fluent in Slavic languages, the article was written in Czech with only a short English abstract. Jirova attempted to revise Rosalina marginata Reuss, 1845, but with an apparently incomplete familiarity with zoological taxonomy and nomenclature, as well as the rules stipulated by the ICZN, instead of solving the previous uncertainty associated with this taxon, the author only managed to create deeper confusion. Incredibly, the writer quoted in the references Reuss's (1854) paper, but did not realize that Reuss clearly redefined his concept of this species both in his description and in an excellent figure (in 1854).

It is necessary to mention, among others, the writer's obvious mistake generated by not adhering to the demands of Article 75 of the ICZN where under "Qualifying conditions", item 75.3.4 stipulates: "the author's reasons for believing the name-bearing type specimen(s) (...) to be lost or destroyed and the steps that have been taken to trace it or them". Cushman (1946) mentioned (p. 150): "The Reuss collections in Dresden, Vienna, and Cambridge have been studied and they are all in agreement". In this situation, in light of ICZN Article 75, the neotype must only be selected from the Reuss collections. Coming back to the present, in the Upper Cretaceous foraminiferal taxonomy, Rosalina marginata REUSS, 1845 emended 1854 is in my opinion a valid taxon.

Because of its test morphology, this species belongs in the genus Dicarinella, and consequently, Reuss's species becomes Dicarinella marginata (REUSS, 1845) REUSS, 1854. In order to avoid nomenclatural confusion introduced by Jirova's article, the correct name of the specimens the writer presented as the neotype of $R$. marginata REUSS, 1845 under the name Globotruncana linneiana marginata (REUSS) is a nomen vernaculum (meaning a "name without taxonomic importance"). What was presented after the publication of the Jirova (1956) article as Globotruncana marginata is a nomen nudum, and I propose to designate all these specimens as Marginotruncana pseudomarginata nomen novum.

It is inexplicable how in 1979 the authors of the volume "Atlas de foraminifères planctoniques du Cretacée superieur (Mer Boreal et Tethys) in the observations presented for Marginotruncana marginata (p. 107) did not comment about Reuss's correction of Rosalina marginata. Also, the above-mentioned volume did not made any comments about manner in which Jirova ignored the ICZN rules by introducing a neotype. By certifying the proposal by Jirova, the authors of the Atlas perpetuated the mistake and infringement of the rules.

Al Shuaibi and Pessagno (2009) in their paper "Emended definition of the Family Marginotruncanidae Pessagno 1967 " discuss the taxonomic validity of this family among the Globotruncanacea. For 1967 this was a correct opinion although not argued well enough. The present article takes care of this problem. The specimens from their Pl. I, Figs. 7-9 correspond to Jirova's 1956 "neotype", which in my opinion is totally different from Reuss' (1845, 1854) opinion, and represents Marginotruncana pseudomarginata nomen novum.

\section{PALEONTOLOGIC DESCRIPTION}

Superfamily Globotruncanacea BROTZEN, 1942

Family Globotruncanidae BROTZEN, 1942

Subfamily Globotruncaninae BROTZEN, 1942

Genus Dicarinella PORTHAULT, 1970

Dicarinella marginata (REUSS, 1845) emend. REUSS, 1854; Plate I, Figs. 10-18.

Rosalina marginata REUSS, 1845, p. 36, Pl. 8, Figs. 54, 74, P1. 13, Fig. 68. REUSS, 1854, p. 69, P1. 26, Fig. 1 a-c.

Reuss's 1845 description: (English adaptation of the original German text). Dimensions (Reuss units - lines); circular shell with a disk aspect, low trochospiral with two whorls, last one with six chambers; in total there are $10 / 12$ oval chambers with an oval arched aspect; all on the spiral side are encircled by a narrow and prominent border. On the exterior part (umbilical side in modern nomenclature) the chambers are discretely arched and separated by small deep sutures more inclined than on the spiral side. The entire umbilical part of the shell is covered by small and prominent spines (figures 54 and 74 on Pl. 8 are too small and therefore not useful for taxonomic purposes).

Reuss 1854: (Reuss dimensions line?) thick circular test with a disk aspect, with the periphery encircled by a straight concave border, deeply in the middle. The spiral side a little bit arched (arcuated) with three whorls, of which the first one is very small, last whorl with 6-8 arched chambers. Each one is encircled by a narrow border at the exterior, and a border somewhat arched. The upper part (umbilical side) of the shell is strongly arched with a large and deeper umbilicus. The uppermost part of the shell (umbilical side) is covered by small spines. The figure from Reuss's Pl. 26, Fig. 1a-c (reproduced in P1. I, Figs. 16-18) now is very helpful for taxonomic purposes.

In conclusion, bringing up to date Reuss's data (text and figures) the diagnosis of this species is: typically low trochospiral test, with the umbilical side with 6 low globular chambers with straight sutures, or weakly arched and depressed without sutural keels or umbilical shoulders; spiral side with arched sutures with weak surrounding keels, the periphery of the test presents two very narrow peripheral keels.

\section{Stratigraphic distribution}

This species is common in the middle-upper Turonian (Sigalitruncana sigali - S. schneegansi biozone).

Family MARGINOTRUNCANIDAE Pessagno, 1967 emend. Al SHUAIBI \& PESSAGNO, 2009

Genus Marginotruncana HOFKER, 1956

Marginotruncana pseudomarginata nom. novum; P1. I, Figs. 1-9

Globotruncana linneiana marginata JIROVA, 1956, NON REUSS, 1845, p. 244, P1. 1, Fig. 1a-c, ("neotype" for Rosalina marginata REUSS, 1845; nom. vernac.).

Marginotruncana marginata (Reuss). Al SHUAIBI \& PESSAGNO, 2009, p. 626; Pl. I, Figs. 7-9.

Remarks

Studia UBB Geologia, 2012, 57 (2), 35 - 38 
This species presented by Jirova (1956) as the neotype for Globotruncana linneiana marginata REUSS, 1845 (P1. 1, Fig. 1a-c or here as a copy, P1. I, Figs. 1-3), differs from Reuss's initial definition (1845-1854) by:

- Chambers with a globular aspect on both the umbilical and spiral sides;

- The presence of two well spaced peripheral keels (a typical character for the genus Marginotruncana);

- The presence of loose sutural keels on the spiral and umbilical sides;

- Sometimes also loose periumbilical shoulders.

\section{CONCLUSIONS}

This article was initiated with the intention to rectify a taxonomic mistake that has generated much confusion. The writers take in evidence the moral-professional correctness of a micropaleontologist to respect "ad literam" the rules and recommendations that must be respected when approaching a taxonomic subject. By this I mean neglecting or ignoring fundamental principles stipulated by the ICZN in order to establish a neotype. Such is the case with "Rosalina" marginata REUSS, 1845 when Jirova (1956) selected a neotype out of any principle excepting the fact that she collected samples from the same location in Bohemia from where Reuss collected in 1845.

In such way a neotype for "Globotruncana linneana marginata (REUSS, 1845)" was introduced in spite of the ICZN's rules. By the manner in which it was introduced, confusion was unintentionally introduced that persists until the present today, tolerated by experienced micropaleontologists (e.g., Caron, 1985, P1. 26, Figs. 3a-c).

Acknowledgments. I am grateful to two anonymous reviewers for their helpful comments and to Mike Kaminski (KFUPM) who corrected the final draft of this manuscript.

\section{R E F E R E N C E S}

Al Shuaibi, A.A., Pessagno, E. 2009, Emended definition of the Family Marginotruncanidae Pessagno 1967. Micropaleontology, 55 (6): 623-626.

Bolli, H.M., Loeblich, A.R. \& Tappan, H. 1957, Planktonic foraminiferal families Hantkeninidae, Orbulinidae, Globorotaliidae and Globotruncanidae U.S. National Museum Bulletin, 215: 1-50.

Caron, M. 1985, Cretaceous planktic foraminifera. In Plankton Stratigraphy (Bolli, H.M, Saunderrs, J.P. \& Perch-Nielsen, Eds.), Cambridge University Press, London, p. 17-86.

Cushman, J.A. 1946, Upper Cretaceous foraminifera of the Gulf Coastal region of the United States and adjacent Areas. U.S. Geological Survey Professional Paper, 206, 241 p. (+66 plates).

Jirova, D. 1956, The genus Globotruncana in the Upper Turonian-Emscherian of Bohemia. Universitas Carolina Geologica, 2 (3): 239-255.

Pessagno, E. (Jr). 1967, Upper Cretaceous planktonic foraminifera from the Western Gulf Costal Plain. Palaeontographica Americana, 5 (37): 1-445.
Robaszinski, F., Caron, M. (Eds.) 1979, Atlas de foraminifères planctoniques du Crétacé Moyen (Mer Boréale et Tethys). Cahiers de Micropaléontologie, 2: 1-185.

Reuss, A.E. 1845, Die Versteinerungen der Böhmischen Kreideformation. E. Schweizerbart, Stuttgart, Abtheilung 1, pt. 2, 148 p.

Reuss, A.E. 1854, Beiträge zur Charakteristik der Kreideschichten in den Ostalpen. Denkschrift der kaiserlichen Akademie der Wissenschaften, matematisch-naturwissenschaftlichen Classe. 7: 1-153.

*** International Code of Zoological nomenclature, adopted by the XV International Congress of Zoology, Published for the International Commission on Zoological Nomenclature, London 1964.

*** International Code of Zoological Nomenclature, Fourth Edition adopted by the International Union of Biological Sciences, The provisions of this Code supersede those of the previous editions with effect from 1 January 2000. 
PLATE I
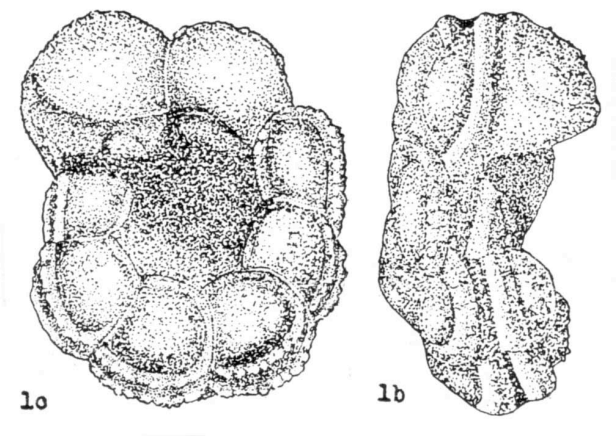

2
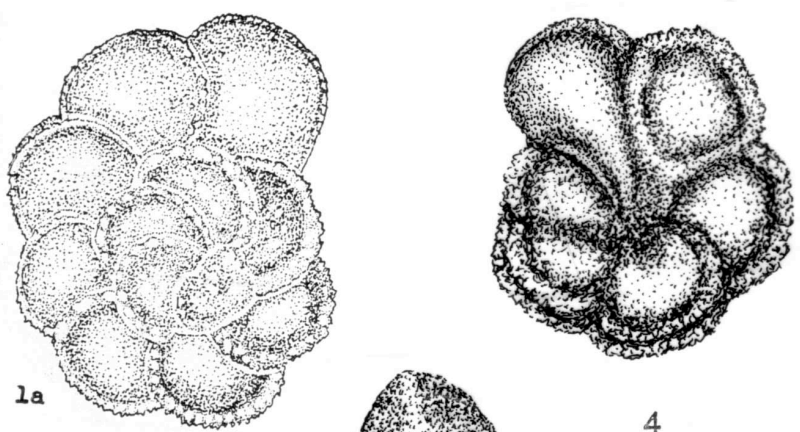

4
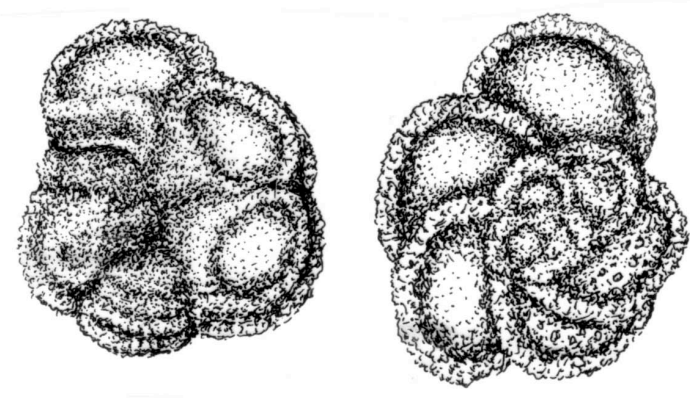

8

3
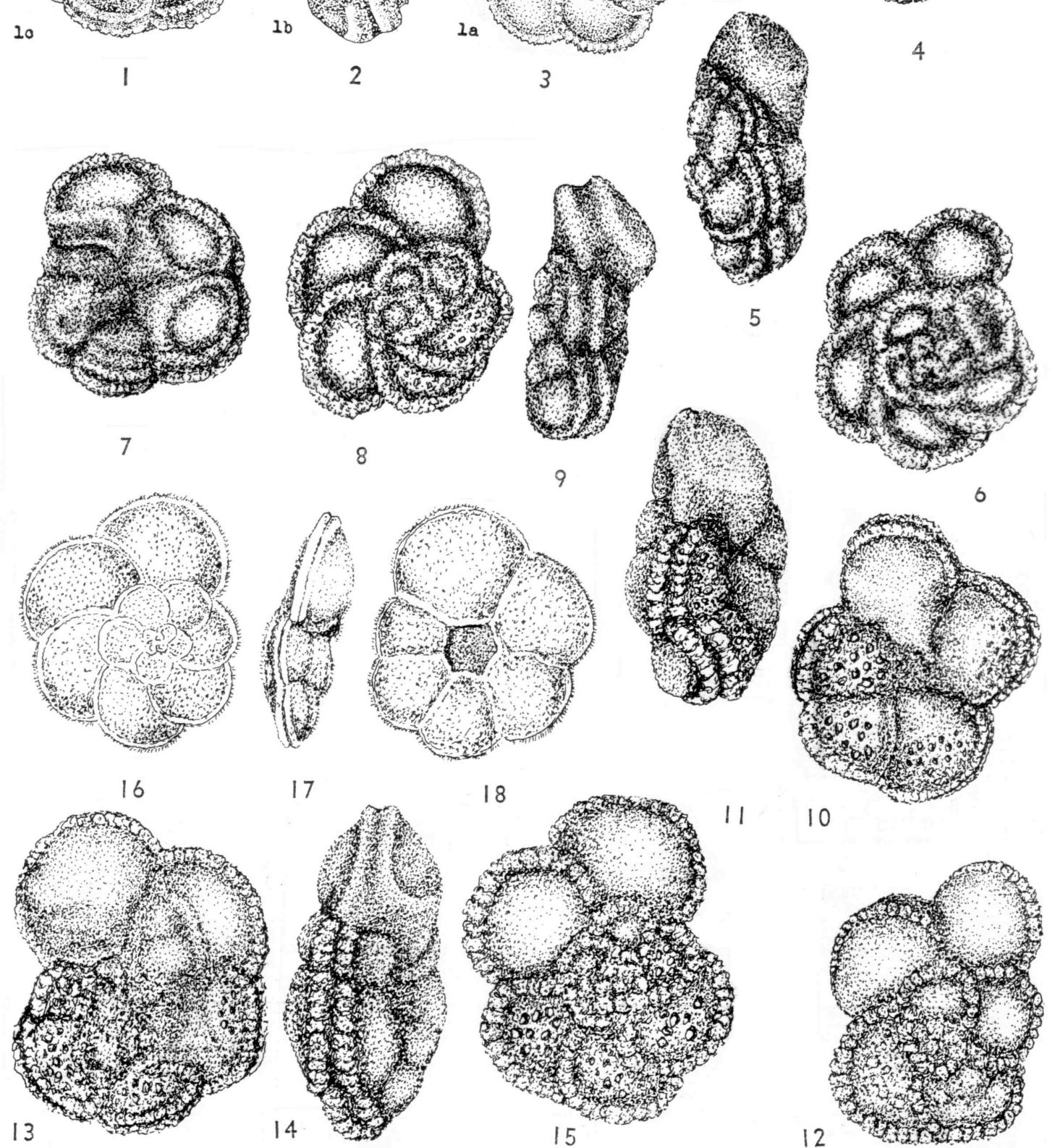

10

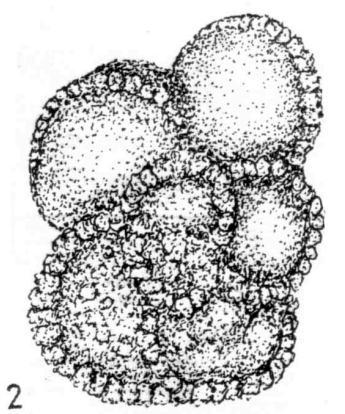

Plate I.

Figs. 1-3. Marginotruncana pseudomarginata nom. nov. pro Globotruncana linneiana marginata JIROVA 1956, non REUSS 1845 (re-illustration of the "Neotype" of Jirova, 1956; P1. 1, Figs. 1a-c; approx. 70x).

Figs. 4-9. Marginotruncana pseudomarginata nom. nov. Upper Turonian-Coniacian, Voivoda Valley, Pietrosita-Ialomita L.P.B.12155 (approx. x70).

Figs. 10-15. Dicarinella marginata (REUSS, 1845) REUSS, 1854. Turonian, Silistea Valley, L.P.B IV.12185 (approx. 70x).

Figs. 16-18. "Rosalina" marginata REUSS, 1854 (re-illustration of Reuss, 1845; Pl. 26, Figs. 1a-c; approx. 70x). 